\title{
PENGARUH KONSENTRASI PATI KENTANG TERHADAP KARAKTERISTIK FISIKOKIMIA DAN ORGANOLEPTIK NUGGET IKAN PATIN-TEPUNG NANGKA MUDA
}

\author{
(Effect of Potato Starch Concentration on Physicochemical and \\ Organoleptic Characteristics of Catfish Nugget with Unripe Jackfruit Flour)
}

\author{
Jessica Dewi Wijaya ${ }^{a^{*}}$, Adrianus Rulianto Utomo $^{a}$, Erni Setijawaty ${ }^{a}$ \\ ${ }^{a}$ Fakultas Teknologi Pertanian, Universitas Katolik Widya Mandala Surabaya, Indonesia \\ ${ }^{*}$ Penulis korespondensi \\ Email: jesssicawijaya2426@gmail.com
}

\begin{abstract}
Nugget is a restructured meat product with the principle of reshaped of meat into a compact form by adding fillers and binders that can determine the quality of the nuggets. Processing catfish into nuggets by modifying the addition of unripe jackfruit flour is one of the efforts to diversify fishery and agricultural products, increase juiciness, and can increase the catfish nugget fiber content. Preliminary research on making catfish nuggets with the proportion of 30\% unripe jackfruit flour showed a decrease in the level of elasticity and the resulting nuggets became less compact. Potato starch can be used as a filler and binder in nuggets. The purpose of this study was to determine the effect of potato starch concentration on the physicochemical and organoleptic properties of catfish nugget with unripe jackfruit flour. The research design used a single factor Randomized Block Design (RBD) consisting of six levels of potato starch concentration which included 3, 6, 9, 12, 15, and 18\% (w/w catfish-unripe jackfruit flour). Tested for physicochemical properties were water content, WHC, oil absorption, emulsion stability, texture, and color. The results showed the influence of potato starch concentration on water content, WHC, oil absorption, texture, and color of the nugget. Increasing the concentration of potato starch can reduce water content, oil absorption, and cohesiveness (at the concentration of potato starch 15-18\%), as well as increasing WHC, hardness, and cohesiveness (concentration of potato starch 3-12\%).
\end{abstract}

Keywords: nugget, catfish, unripe jackfruit flour, potato starch

\begin{abstract}
ABSTRAK
Nugget merupakan salah satu produk restructured meat dengan prinsip penyatuan kembali potonganpotongan daging menjadi suatu bentuk utuh yang kompak dengan menambahan bahan pengisi (filler) dan pengikat (binder) yang dapat menentukan kualitas nugget. Pengolahan ikan patin menjadi nugget dengan modifikasi penambahan tepung nangka muda merupakan salah satu upaya diversifikasi hasil perikanan dan pertanian, meningkatkan juiciness, serta dapat meningkatkan kandungan serat nugget ikan patin. Penelitian pendahuluan pembuatan nugget ikan patin dengan proporsi $30 \%$ tepung nangka muda menunjukkan terjadinya penurunan tingkat kekenyalan dan nugget yang dihasilkan menjadi kurang kompak. Upaya peningkatan kualitas nugget dapat dilakukan dengan penambahan pati kentang sebagai filler dan binder dalam nugget. Tujuan penelitian ini adalah untuk mengetahui pengaruh konsentrasi pati kentang terhadap sifat fisikokimia dan organoleptik nugget ikan patin-tepung nangka muda. Rancangan penelitian yang digunakan adalah Rancangan Acak Kelompok (RAK) faktor tunggal yang terdiri dari enam taraf konsentrasi pati kentang, yaitu 3, 6, 9, 12, 15, dan 18\% (b/b ikan patin-tepung nangka muda). Pengujian terhadap karaktertistik fisikokimia meliputi uji kadar air, WHC, daya serap minyak, kestabilan emulsi, tekstur, dan warna. Hasil penelitian menunjukkan adanya pengaruh konsentrasi pati kentang terhadap kadar air, WHC, daya serap minyak, tekstur, dan warna nugget. Peningkatan konsentrasi pati kentang dapat menurunkan kadar air, daya serap minyak, dan cohesiveness (konsentrasi pati kentang $15-18 \%$ ), serta meningkatkan WHC, hardness, dan cohesiveness (konsentrasi pati kentang 3-12\%).
\end{abstract}


Kata kunci: Nugget, ikan patin, tepung nangka muda, pati kentang

\section{PENDAHULUAN}

Nugget merupakan salah satu produk restructured meat dengan prinsip penyatuan kembali potongan-potongan daging menjadi suatu bentuk utuh yang kompak dengan menambahkan bahan pengisi (filler) dan pengikat (binder) yang dapat menentukan kualitas nugget (Amertaningtyas, 2001). Salah satu upaya diversifikasi produk nugget adalah dengan menggunakan ikan patin dan modifikasi dengan penambahan tepung nangka muda. Parameter penting pada produk nugget adalah tekstur yang memberi sifat juiciness dan keempukan yang mempengaruhi kenampakan produk akhir (Utiarahman dkk., 2013).

Berdasarkan penelitian pendahuluan, pembuatan nugget ikan patin dengan proporsi $30 \%$ tepung nangka muda menunjukkan terjadinya penurunan tingkat kekenyalan dan nugget yang dihasilkan menjadi kurang kompak. Oleh karena itu, perlu dilakukan upaya untuk memperbaiki kualitas produk nugget ikan patin dengan penambahan binder dan filler. Fungsi filler adalah meningkatkan daya ikat air, mengurangi pengerutan selama pemasakan, meningkatkan karakteristik fisik dan kimiawi serta sensori produk (Adelita, 2010). Bahan yang dapat digunakan sebagai filler maupun binder adalah bahan yang mengandung pati dalam jumlah tinggi, salah satunya adalah pati kentang.

Penambahan pati kentang dalam produk restructured meat seperti nugget berkontribusi terhadap sifat tekstur dan meningkatkan kekuatan gel dari struktur matriks gel protein (Akta dan Gençcelep, 2006). Pati kentang dianggap sebagai produk yang ideal digunakan karena suhu gelatinisasi yang rendah dan kapasitas pengikatan air yang tinggi (Barbut, 2005). Pati kentang memiliki ukuran granula pati yang lebih besar (1-100 $\mu \mathrm{m})$ sehingga memiliki kemampuan menyerap air yang lebih tinggi (Peng et al., 1999). Kemampuan menyerap air pada pati kentang yang tinggi mampu meningkatkan jumlah air yang dapat terikat dan dapat mengurangi kekerasan tekstur karena lebih banyak air ditahan dalam matriks gel komposit proteinpati (Liu et al., 2008).

Pada penelitian nugget ikan patintepung nangka muda dilakukan penambahan pati kentang pada berbagai konsentrasi, yaitu 3\%,6\%, 9\%, 12\%, 15\%, dan $18 \%$. Penambahan pati kentang di atas $18 \%$ dapat menyebabkan penurunan tingkat kekompakan tekstur nugget yang dihasilkan. Penambahan pati kentang pada berbagai konsentrasi bertujuan untuk mengetahui sifat fisikokimia dan prganoleptik nugget ikan patin-tepung nangka muda yang dihasilkan. Oleh karena itu, perlu dilakukan penelitian tentang pengaruh pati kentang terhadap karakteristik fisikokimia dan organoleptik nugget ikan patin-tepung nangka muda.

\section{Bahan dan Alat}

\section{BAHAN DAN METODE}

Bahan-bahan yang digunakan untuk membuat nugget ikan patin-tepung nangka muda meliputi daging ikan patin yang diperoleh di pasar lokal Surabaya, tepung nangka muda yang diolah dari nangka salak yang masih muda, pati kentang (Avebe), bread crumb mix, air es, telur ayam negeri, bawang putih segar, garam dapur, gula pasir, merica, minyak goreng, kertas merang, dan kertas roti.

Alat yang digunakan dalam proses pengolahan nugget ikan patin- tepung nangka muda, yaitu chopper daging (Matrix SY-22), chopper bumbu dan motor (Phillips), neraca digital (SF-400), dandang berukuran 40x40x23 cm, tray, cabinet dryer (Wangdi W.), thermometer, tali, baskom stainless steel, sendok, solet, pisau, telenan, piring plastik, loyang aluminium

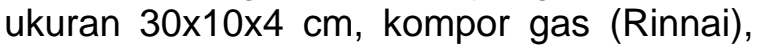
nampan plastik, deep fryer (Fritel Profesional), freezer (Rotary Mitsubishi MR428W), penggaris, ayakan 25 mesh 
(Retshc), dan plastik kemasan PE.

Alat analisa yang digunakan meliputi neraca analitis (Ohaus), botol timbang (RRC), eksikator (RRC), oven (Binder), sarung tangan, blender dan motor (Philips), $\mathrm{pH}$ meter (MicroBech T12100) handrefractometer, color reader (Minolta CR-20), texture profile analyzer (TA-XT Plus), tabung centrifuge (Pyrex), centrifuge (Hettich Zentrifugen D78532 Tuttlingen), gelas ukur 10 dan $100 \mathrm{~mL}$ (Pyrex), beaker glass 100, 250, $400 \mathrm{~mL}$ (Pyrex), vortex (Lab Dancer Vario3 417700), pipet tetes, pengaduk kaca, termometer, dan freezer (Rotary Mitsubishi MR428W).

\section{Metode penelitian}

Formulasi yang digunakan pada pengolahan nugget ikan patin- tepung nangka muda dapat dilihat pada Tabel 1 . dan Tabel 2.

Pengujian yang dilakukan meliputi analisa sifat fisikokimia dan organoleptik nugget ikan patin-tepung nangka muda. Analisa sifat fisikokimia (kadar air, WHC, daya serap minyak, kestabilan emulsi, tekstur, dan warna) menggunakan Rancangan Acak Kelompok (RAK) faktor tunggal yang terdiri dari enam taraf perlakuan dan diulang sebanyak empat kali sehingga terdapat dua puluh empat unit perlakuan. Enam taraf perlakuan yang diujikan, yaitu penambahan konsentrasi pati kentang 3\% $\left(\mathrm{K}_{3}\right), 6 \%\left(\mathrm{~K}_{6}\right), 9 \%\left(\mathrm{~K}_{9}\right), 12 \%$ $\left(K_{12}\right), 15 \%\left(K_{15}\right)$, dan $18 \%\left(K_{18}\right)$.

\section{Pembuatan Nugget Ikan Patin-Tepung Nangka Muda}

Proses pembuatan nugget ikan patintepung nangka muda diawali dengan penyiangan dan pemotongan daging ikan patin. Selanjutnya dilakukan penggilingan daging ikan patin, tepung nangka muda, dan pati kentang yang telah ditimbang sesuai dengan formulasi dengan menggunakan chopper selama 40 detik. Sebanyak 500 gram campuran daging ikan patin, tepung nangka muda, dan pati kentang dari masing- masing perlakuan yang telah halus, dicampur dengan putih telur dan bumbu halus yang telah ditimbang pada baskom stainless steel. Adonan nugget selanjutnya dicetak pada loyang dengan ukuran $30 \times 10 \times 23 \mathrm{~cm}$ yang telah diolesi dengan margarin dengan ketebalan $\pm 1 \mathrm{~cm}$. Adonan dikukus dalam dandang pada suhu $100^{\circ} \mathrm{C}$ selama 30 menit. Adonan yang telah matang didinginkan pada suhu kamar. Adonan selanjutnya dipotong dengan ukuran $4 \times 4 \times 1 \mathrm{~cm}$ dan dilanjutkan dengan coating.

Coating terdiri dari dua tahap, yaitu battering dan breading. Battering dilakukan dengan pencelupan potongan adonan pada batter campuran terigu, tapioka, dan air dengan proporsi $1: 1: 3$, lalu proses breading dilakukan dengan melapisi adonan dengan bread crumbs mix (breading). Penggorengan nugget dilakukan dua kali, yaitu pre-frying dan frying. Pre-frying dilakukan pada suhu $170^{\circ} \mathrm{C}$ selama 30 detik dengan metode deep frying untuk mematangkan batter. Nugget pre-fried disimpan disimpan dalam freezer selama 12 jamn untuk selanjutnya digoreng nugget pada suhu $170^{\circ} \mathrm{C}$ selama 1 menit dan dianalisa sifat fisikokimia dan organoleptiknya.

\section{HASIL DAN PEMBAHASAN}

Pengujian sifat fisikokimisa nugget ikan patin-tepung nangka muda meliputi kadar air, WHC, daya serap minyak, kestabilan emulsi, tekstur, dan warna. Hasil pengujian dapat dilihat pada Tabel 3 .

\section{Kadar Air}

Pengujian kadar air bertujuan untuk mengetahui jumlah air bebas dalam nugget ikan patin-tepung nangka muda dengan penambahan pati kentang pada berbagai konsentrasi yang berbeda. Kadar air nugget ikan patin-tepung nangka muda berkisar antara $61,28 \%$ hingga $63,99 \%$. Kadar air nugget cenderung menurun dengan meningkatnya konsentrasi pati kentang karena adanya peningkatan ikatan ionik yang kuat dalam mempertahankan stabilitas 
Tabel 1. Formulasi Campuran Ikan Patin, Tepung Nangka Muda, dan Pati Kentang

\begin{tabular}{lcccccc}
\hline \multirow{2}{*}{ Bahan } & $\mathrm{K}_{3}$ & $\mathrm{~K}_{6}$ & $\mathrm{~K}_{9}$ & $\mathrm{~K}_{12}$ & $\mathrm{~K}_{15}$ & $\mathrm{~K}_{18}$ \\
\cline { 2 - 7 } & 350 & 350 & 350 & 350 & 350 & 350 \\
\hline Ikan patin (g) & 150 & 150 & 150 & 150 & 150 & 150 \\
Tepung nangka muda (g) & 15 & 30 & 45 & 60 & 75 & 90 \\
Pati kentang (g) & 515 & 530 & 545 & 560 & 575 & 590 \\
\hline Total (g) &
\end{tabular}

Tabel 2. Formulasi Nugget Ikan Patin-Tepung Nangka Muda

\begin{tabular}{lcccccc}
\hline & \multicolumn{7}{c}{ Perlakuan } \\
\cline { 2 - 7 } & $\mathrm{K}_{3}$ & $\mathrm{~K}_{6}$ & $\mathrm{~K}_{9}$ & $\mathrm{~K}_{12}$ & $\mathrm{~K}_{15}$ & $\mathrm{~K}_{18}$ \\
\hline Formulasi campuran (ikan patin, Tepung & 500 & 500 & 500 & 500 & 500 & 500 \\
nangka muda, pati kentang) (g) & 100 & 100 & 100 & 100 & 100 & 100 \\
Putih telur (g) & 60 & 60 & 60 & 60 & 60 & 60 \\
Bawang putih (g) & 12,5 & 12,5 & 12,5 & 12,5 & 12,5 & 12,5 \\
Garam (g) & 5 & 5 & 5 & 5 & 5 & 5 \\
Gula (g) & 5 & 5 & 5 & 5 & 5 & 5 \\
Merica (g) & 275 & 275 & 275 & 275 & 275 & 275 \\
Air es (g) & 957,5 & 957,5 & 957,5 & 957,5 & 957,5 & 957,5 \\
\hline Total (g) & & & & & &
\end{tabular}

Tabel 3. Hasil Pengujian Sifat Fisikokimia dan Organoleptik Nugget Ikan Patin-Tepung Nangka Muda

\begin{tabular}{lcccccc}
\hline \multirow{2}{*}{ Parameter } & \multicolumn{7}{c}{ Perlakuan } \\
\cline { 2 - 7 } & $\mathrm{K}_{3}$ & $\mathrm{~K}_{6}$ & $\mathrm{~K}_{9}$ & $\mathrm{~K}_{12}$ & $\mathrm{~K}_{15}$ & $\mathrm{~K}_{18}$ \\
\hline Kadar Air (\%) & $63,99^{\mathrm{c}}$ & $63,61^{\mathrm{c}}$ & $63,38^{\mathrm{b}}$ & $62,62^{\mathrm{b}}$ & $61,92^{\mathrm{a}}$ & $61,28^{\mathrm{a}}$ \\
WHC sebelum goreng (\%) & $63,06^{\mathrm{a}}$ & $73,62^{\mathrm{b}}$ & $79,40^{\mathrm{c}}$ & $86,08^{\mathrm{d}}$ & $96,46^{\mathrm{e}}$ & $114,53^{\mathrm{f}}$ \\
WHC setelah goreng (\%) & $127,22^{\mathrm{a}}$ & $134,86^{\mathrm{b}}$ & $143,93^{\mathrm{c}}$ & $158,07^{\mathrm{d}}$ & $206,62^{\mathrm{e}}$ & $216,4^{\dagger}$ \\
Daya serap minyak (\%) & $11,26^{\mathrm{c}}$ & $10,89^{\mathrm{c}}$ & $9,06^{\mathrm{b}}$ & $8,49^{\mathrm{ab}}$ & $7,67^{\mathrm{a}}$ & $7,47^{\mathrm{a}}$ \\
Kestabilan emulsi (\%) & 100 & 100 & 100 & 100 & 100 & 100 \\
Tekstur & & & & & & \\
- Hardness (g) & $6101,66^{\mathrm{a}}$ & $6448,41^{\mathrm{b}}$ & $6679,88^{\mathrm{bc}}$ & $6996,59^{\mathrm{c}}$ & $8587,27^{\mathrm{d}}$ & $8796,41^{\mathrm{d}}$ \\
- Cohesiveness & $0,21^{\mathrm{a}}$ & $0,30^{\mathrm{ab}}$ & $0,42^{\mathrm{bc}}$ & $0,47^{\mathrm{c}}$ & $0,30^{\mathrm{ab}}$ & $0,26^{\mathrm{ab}}$ \\
Warna & & & & & & \\
- Lightness & 56,33 & 54,88 & 54,03 & 53,90 & 51,73 & 49,20 \\
- Redness (a*) & 8,75 & 8,25 & 7,70 & 7,70 & 7,30 & 6,78 \\
- Yellowness (b*) & 17,93 & 16,80 & 14,80 & 14,58 & 13,73 & 13,03 \\
- Hue (年) & 63,87 & 63,84 & 62,51 & 62,13 & 61,91 & 62,41 \\
- Chroma & 19,96 & 18,72 & 16,69 & 16,49 & 15,56 & 14,69 \\
\hline
\end{tabular}

gel pati-protein (Winarno, 2002) sehingga semakin sedikit jumlah air bebas dalam bahan yang dapat diuapkan dan semakin rendah kadar air yang dihasilkan.

\section{Water Holding Capacity (WHC)} Water Holding Capacity (WHC) didefinisikan sebagai kemampuan bahan untuk menahan airnya sendiri dan air yang ditambahkan selama ada gaya, tekanan, sentrifugasi, atau pemanasan. WHC nugget ikan patin-tepung nangka muda sebelum penggorengan berkisar antara 63,06\% hingga 114,53\% sedangkan WHC nugget setelah penggorengan berkisar antara $127,22 \%$ hingga $216,49 \%$. WHC nugget ikan patin-tepung nangka muda sebelum dan sesudah penggorengan meningkat karena kemampuan penyerapan air yang lebih tinggi dan adanya ikatan yang kuat antara gugus hidroksil amilosa dengan air yang mampu mempertahankan stabilitas gel 
protein-pati

sehingga

mampu

mempertahankan air dalam gel.

\section{Daya Serap Minyak}

Daya serap minyak nugget ikan patintepung nangka muda dengan penambahan pati kentang berkisar antara 7,47-11,26\%. Daya serap minyak nugget ikan patintepung nangka muda dengan penambahan pati kentang $15 \%$ dan $18 \%$ lebih rendah dibandingkan dengan 3\%, 6\%, 9\%, dan $12 \%$. Semakin tinggi konsentrasi pati kentang yang ditambahkan, daya serap minyak nugget ikan patin-tepung nangka muda cenderung turun karena tejadi stabilitas matriks gel pati-protein yang padat menyebabkan ruang antar partikel semakin sempit sehingga semakin banyak air yang dapat dipertahankan sedangkan penyerapan minyak menurun.

\section{Kestabilan Emulsi}

Nugget ikan patin-tepung nangka muda dengan penambahan konsentrasi pati kentang memilki sistem emulsi yang stabil. Sistem emulsi dapat dipertahankan stabil setelah terjadinya gelatinisasi pati apabila droplet minyak terperangkap oleh pati gel sehingga dapat mencegah terbentuknya creaming dan kestabilan emulsi dapat dipertahankan (Tzoumaki et al., 2011).

\section{Tekstur}

$\begin{array}{lll}\text { Nilai hardness } & \text { tekstur nugget } \\ \text { berkisar } & \text { antara } & 6101,66-8796,41\end{array}$ sedangkan cohesiveness nugget berkisar antara 0,21-0,47. Hardness nugget ikan patin-tepung nangka muda cenderung meningkat dengan bertambahnya konsentrasi pati kentang yang ditambahkan. Penambahan pati kentang meningkatkan kekuatan gelasi protein daging, membentuk gel yang lebih kuat dan meningkatkan daya tahan produk terhadap kompresi (Kim and Lee, 1987). Cohesiveness nugget ikan patin-tepung nangka muda cenderung meningkat hingga penambahan pati kentang $12 \%$. Penambahan pati kentang lebih dari $12 \%$ menunjukkan nilai cohesiveness nugget cenderung menurun. Penurunan cohesiveness disebabkan karena hidrasi air yang tidak mencukupi akibat lebih banyak air terperangkap dalam matriks gel protein- pati sehingga pembengkakan granula pati terbatas menyebabkan melemahnya struktur gel (Liu et al., 2008).

\section{Warna}

Hasil pengujian menunjukkan nilai lightness berkisar antara 49,20-56,33; nilai $a^{*}$ berkisar antara $6,78-8,75$; nilai $b^{*}$ berkisar antara 13,03-17,93; nilai Hue berkisar antara 61,91-63,87 dan nilai chroma berkisar antara 14,69-19,96. Warna nugget ikan patin-tepung nangka muda yang dihasilkan berwarna coklat gelap dengan unsur merah dan kuning yang berasal dari tepung nangka muda yang digunakan.

\section{KESIMPULAN}

Perbedaan penambahan konsentrasi pati kentang berpengaruh terhadap sifat fisikokimia nugget ikan patin-tepung nangka muda, yaitu penurunan kadar air $(61,28-63,99 \%)$, daya serap minyak $(7,47-$ $11,26 \%)$, dan cohesiveness pada konsentrasi $15-18 \% \quad(0,26-0,30)$, serta peningkatan WHC sebelum goreng $(63,06 \%-114,53 \%)$ dan sesudah goreng $(127,22-216,49 \%)$, hardness (6101,668796,41), dan cohesiveness pada konsentrasi $3-12 \% \quad(0,21-0,47)$. Warna nugget ikan patin-tepung nangka muda cenderung coklat gelap dengan nilai $\mathrm{L}, \mathrm{a}^{*}$, $\mathrm{b}^{*}$, hue, dan chroma berturut- turut sebesar 49,20-56,33; 6,78-8,75; 13,03-17,93; 62,41-63,87; dan 14,69-19,96. Perlu dilakukan penelitian lebih lanjut untuk mengetahui formulasi yang tepat sehingga dapat diperoleh nugget dengan rasa dan juiciness yang lebih baik serta lama penyimpanan nugget ikan patin-tepung nangka muda.

\section{DAFTAR PUSTAKA}

Adelita, H. 2010. Pengaruh Substitusi 
Daging Ayam dengan Tepung Kedelai terhadap Kualitas Kimia dan Mikrostruktur Chicken Nugget, Skripsi, Fakultas Peternakan, Universitas Brawijaya, Malang.

Aktaş, N. and Gençcelep, H. 2006. Effect of Starch Type and Its Modifications on Physicochemical Properties of Bologna-Type Sausage Produced with Sheep Tail Fat, Meat Science. 74: 404-408.

Amertaningtyas, D., Purnomo, H., dan Siswanto. 2001. Kualitas Nuggets Daging Ayam Broiler dan Ayam Petelur Afkir dengan Menggunakan Tapioka dan Tapioka Modifikasi Serta Lama Pengukusan yang Berbeda, Tesis, Program Pasca Sarjana Universitas Brawijaya, Malang.

Barbut, S. 2002. Poultry Products Processing, An Industry Guide. Boca Raton: CRC Press.

Kim, J. M. and Lee, C. M. 1987. Effect of Starch of Textural Properties of Surimi Gel, Journal of Food Science. 52(3): 722-725.

Liu, H., Y.L. Xiong, L. Jiang, and B. Kong. 2008. Fat Reduction in Emulsion Sausage Using An Enzyme-Modified Potato Starch, Journal of the Science of Food and Agriculture. 88(9):1632 1637.
Peng, M., M. Gao, E.S.A. Abdel, R.N. Chibbar. 1999. Separation and Characterization of A- and B- type Starch Granules in Wheat Endosperm, Cereal Chem. 76 (3): 375-379.

Utiarahman, G., Harmain, R. M., Yusuf, N. 2013. Karakteristik Kimia dan Organoleptik Nugget Ikan Layang (Decapterus Sp.) yang Disubtitusi dengan Tepung Ubi Jalar Putih (Ipomea Batatas L), Jurnal IImiah Perikanan dan Kelautan, Universitas Negeri Gorontalo. 1(3): 10.

Winarno, F.G. 2002. Kimia Pangan dan Gizi. Jakarta: PT. Gramedia Pustaka Utama. 